\title{
Technological memory as a teaching management tool for the development of social promotion projects in universities
}

\author{
Esther S. Zárate ${ }^{\# 1}$, Raúl J. Martelo ${ }^{* 2}$, David Franco ${ }^{* 3}$ \\ \# University of La Guajira Riohacha, La Guajira, Colombia. \\ ${ }^{1}$ szarate@uniguajira.edu.co \\ *Faculty of Engineering, University of Cartagena Cartagena, Bolívar, Colombia. \\ 2 rmartelog1@unicartagena.edu.co \\ 3 dfrancon@unicartagena.edu.co
}

\begin{abstract}
In the present study, the technological memory was analyzed as a teaching management tool for the development of Social Promotion projects at the University of La Guajira, Fonseca headquarters, Colombia. 62 teachers were consulted using as an instrument a scale of opinion, to diagnose the management carried out by the teachers, to determine if they make use of the technological memory as a management tool and to describe the projects of Social Promotion. The results allow concluding that teachers reflect weaknesses related to the application of managerial functions. In addition, they show few competences related to the prevention of participation, innovation, dynamization and methodology in the development of Social Promotion projects. Consequently, it is recommended to guide the management of the teacher in terms of the development of Social Promotion projects using the Technology Memory.
\end{abstract}

Keyword- Social Promotion Projects, resources control, educational actors, dynamization

\section{INTRODUCTION}

The amount of information that is generated, makes society based on knowledge and due to the diffusion caused by Information and Communication Technologies (ICT), the education system is required to constitute a vision where the way in which it changes it is possible to build and consolidate learning, to improve the quality of education and to reform the way information is obtained and managed [1]. Consequently, education and teaching institutions try to avoid traditional methods despite their validity and successful results, and focus their interest on the most productive methods that improve the learning experience and the intellectual level of students [2]. That is why they have generated multiple discussions, forums, talks and research on the profile of the teacher that is needed to train human beings able to perform in a computerized and technified society.

From this perspective, current educational organizations must be framed in dimensions of change, so that their management process requires committed, innovative teachers, capable of challenging the technical, scientific and social advances required by the scenarios demanded by society. That is, the teacher needs to have solid conceptual bases and skills to administer the classes in such a way that knowledge is correctly established [3]. In this regard, the Echelon higher theory focuses on the characteristics of senior managers, such as age, function marks, other professional experience, education, socioeconomic roots, financial status, and group characteristics [4]. The theory states that the results of the organization, strategic decisions and performance levels are partially predicted by the management characteristics [5].

Therefore, it is necessary to analyze the management skills and ICT skills of teachers for the development of projects, using technology memory. In this regard, in [6] they related the management skills of distance teachers with the education of the conventional ones, in order to ensure the quality of training. Likewise, in [7] they identified the management skills that the teachers of secondary schools possess, in order to determine the activities that affect their performance in the classroom management. On the other hand, [8] they developed a standard for teachers that contains the ICT competencies they must possess, through the implementation of the Delphi technique. In [9] digital competence was integrated into teacher training programs, in order to train professionals who can provide and use tools that support the teaching-learning process.

Considering what has been described, the technological memory becomes a tool in the teaching process, as it allows the development of social promotion projects, the elaboration of contents for both theory and practice, giving a pedagogical and didactic use. Therefore, through the technological memory will generate social spaces as well as a community, which contribute to the progress of the individual and collective potential of teachers and society. Therefore, the main purpose of this research is to analyze the technological memory as a teaching management tool for the development of social promotion projects at the University of La Guajira, Fonseca, Colombia. 


\section{Methodology}

The research was non-experimental descriptive cross-sectional. Not experimental because the behavior of the variables was observed without controlling it [10]. Cross-sectional because data were collected in a single moment, in a single time, its purpose was to describe the variables, and analyze their incidence and interrelation at a given time [11]. The study population consisted of: 62 teachers belonging to the University of Guajira Fonseca headquarters for the year 2016. Because the population is finite and accessible, it will not be necessary to carry out sampling, for which a census was applied [12].

\section{A. Research instruments}

As a research technique the survey was used, as a data collection instrument, a questionnaire of 19 scalar questions inherent to the dimensions was used: Teacher management (items 1 to 8); Technological memory as a management tool (items 9 to 14) and Social promotion projects in teacher management (items 15 to 19). The items were presented in a format of five (5) points for the analysis alternatives: Always (5), Almost Always (4) Sometimes (3) Almost Never (2) and Never (1). In reference to its validity and reliability, it was reviewed by experts in the area, estimating later (pilot test) the Cronbach's Alpha coefficient, which yielded a result of 0.87 .

\section{B. Data analysis}

Once the collection instrument was applied, the data were sorted, tabulated and analyzed, using descriptive statistics. The information was presented in terms of absolute frequencies, percentages and arithmetic averages by alternative answers, illustrating the latter in graphs and interpreting it in light of the theoretical foundations and background of the research.

\section{III.RESULTS}

These results are summarized in absolute frequencies, percentages and arithmetic averages. The tables and figures are presented according to the variable, dimension and indicators, with their corresponding analysis of results.

\section{A. Variable: Technologic Memory - Dimension: Teaching management}

Table 1 and Figure 1 show the results corresponding to the Teaching Management dimension, expressed through the indicators: planning, organization, direction and control.

TABLE I. Dimension: Teaching management

\begin{tabular}{|c|c|c|c|c|c|c|c|c|c|c|c|c|}
\hline $\begin{array}{c}\text { Answer } \\
\text { categories }\end{array}$ & \multicolumn{2}{|c|}{ Always 5} & \multicolumn{2}{|c|}{ Almost always 4} & \multicolumn{2}{|c|}{ Sometimes 3} & \multicolumn{2}{|c|}{ Almost never 2} & \multicolumn{2}{|c|}{ Never 1} & \multirow[t]{2}{*}{\begin{tabular}{|l|}
$\begin{array}{c}\text { weighted } \\
\text { average }\end{array}$ \\
\end{tabular}} & \multirow[t]{2}{*}{ Category } \\
\hline Indicators & af & $\%$ & af & $\%$ & af & $\%$ & af & $\%$ & & & & \\
\hline $\begin{array}{l}\text { Planing } \\
\text { Item 1-2 }\end{array}$ & 3 & 4.84 & 6 & 9.68 & 25 & 40.32 & 20 & 32.26 & 8 & 12.90 & 2.61 & unfavorable \\
\hline $\begin{array}{l}\text { Organization } \\
\text { Item 3-4 }\end{array}$ & 6 & 9.68 & 8 & 12.90 & 24 & 38.71 & 18 & 29.03 & 6 & 9.68 & 2.83 & $\begin{array}{c}\text { Moderately } \\
\text { Favorable }\end{array}$ \\
\hline $\begin{array}{l}\text { Direction } \\
\text { Item 5-6 }\end{array}$ & 4 & 6.45 & 12 & 19.35 & 30 & 48.39 & 12 & 19.35 & 4 & 6.45 & 3.03 & $\begin{array}{c}\text { Moderately } \\
\text { Favorable }\end{array}$ \\
\hline $\begin{array}{l}\text { Control } \\
\text { Item 7-8 }\end{array}$ & 7 & 11.29 & 10 & 16.13 & 25 & 40.32 & 15 & 24.19 & 5 & 8.06 & 2.98 & $\begin{array}{c}\text { Moderately } \\
\text { Favorable }\end{array}$ \\
\hline Averages & 5 & 8.07 & 9 & 14.52 & 26 & 41.94 & 16 & 26.20 & 6 & 9.27 & 2.86 & $\begin{array}{c}\text { Moderately } \\
\text { Favorable }\end{array}$ \\
\hline $\begin{array}{l}\text { Average of the } \\
\text { Dimension }\end{array}$ & \multicolumn{12}{|c|}{2.86} \\
\hline Category & \multicolumn{12}{|c|}{ Moderately Favorable } \\
\hline
\end{tabular}




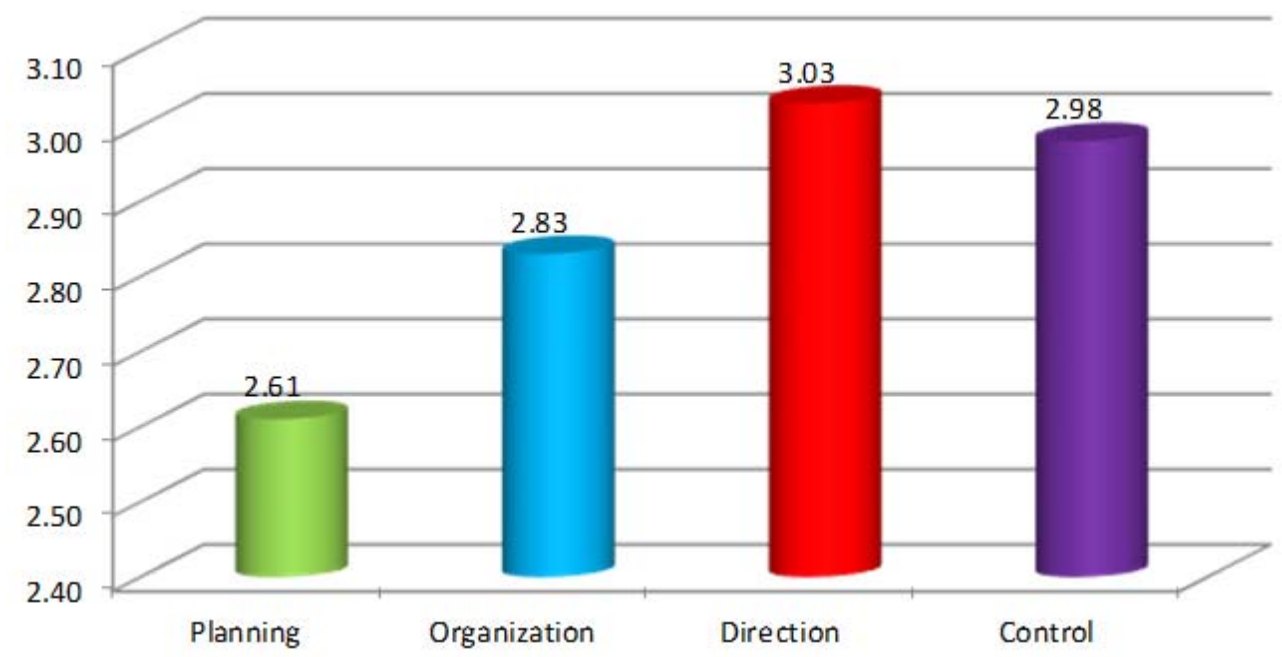

Fig. 1: Representation of the arithmetic means of the indicators of the Teaching Management dimension

The values of the arithmetic average reflect a behavior with a moderately favorable trend. Consequently, an arithmetic mean positioned in the moderately agreed category was obtained for the dimension.

The responses of the Planning indicator show a moderately favorable trend. The highest position was in the alternative "sometimes", followed "almost never" and "never", for a sum of $85.48 \%$, a value that indicates the scarce frequency with which the teachers plan the actions framed in the integral vision of the organization that respond to the demands of their position, establishing the characteristics for unforeseen situations and control, nevertheless a $9.68 \%$ position was "almost always" and $4.84 \%$ "always". The results obtained allow us to consider that teachers scarcely plan Social Promotion projects according to the needs of the communities to which it is addressed, based on the Technology Report. In this indicator an arithmetic average of 2.61 was obtained, which corresponds to the unfavorable category.

Regarding the Organization indicator, the answers most issued by the teachers investigated correspond to the alternative sometimes, followed almost never and never, for a total of $77.42 \%$, which indicate that teachers usually establish joint actions with the members of the community for the elaboration of the projects of Social Promotion oriented in the technological Memory, nevertheless a 12.90\% inclined towards the option almost always and $9.68 \%$ in always consider that yes they do it; the value of the arithmetic average, located in the moderately favorable category corroborates the analyzed. Taking these results into account, it is concluded that teachers do not organize group sessions of an academic nature to guide community members to participate in activities that benefit both the institution and them, making use of the technological memory.

In the data obtained from the analysis of the Direction indicator, the responses were discriminated as follows: first, it was recorded in a few times, followed almost always and almost never, ending with the lowest values, in equal proportion, of always and never, results that reflect that the majority of teachers moderately guide the students in the implementation of the projects of Social Promotion based on the Technological Memory, indicating that the teaching staff shows signs of weaknesses in the application of the function address, nevertheless a $19.35 \%$ in almost always and $6.45 \%$ in always affirm that this activity is carried out. It should be noted that in this indicator, the calculated arithmetic mean was 3.03, located in the moderately favorable category. Therefore, it is necessary to apply this function in teacher management, with the purpose of forming proactive groups where integrative and collaborative actions are visualized among the different educational actors in the institutional environment.

Around the Control indicator, responses were mostly located in the alternative sometimes, complemented by almost never and then never, obtaining a sum of $72.57 \%$, although it is significant to note that overall $27.42 \%$ was recorded almost always and always, a situation that reflects that teachers moderately control the resources to be used for the development of Social Promotion projects with the help of those involved in the educational process, as well as little evaluate the activities carried out by students to make the necessary corrections. The analysis of these results allows us to consider that in the teaching management of teachers, the control reflects a moderately favorable trend, as well as the total arithmetic average obtained in the same category.

The generality of the results corresponding to the teacher management dimension analyzed through the indicators: planning, organization, direction and control, show a moderately favorable assessment by teachers, particularly in the planning where social promotion projects are scarcely planned, taking into account the technological Memory. Likewise, shortcomings are needed in order to direct actions to achieve the integration of students to the Social Promotion project based on the Technology Memory. Finally, in the control function, 
the absence of stimuli towards shared actions prevails, which is limiting with the successful teaching management of teaching staff in the exercise.

The results found do not match what was proposed by [13], who is exposing that the Manager is an individual who thinks, makes decisions, entrepreneur and supporter of the approach of the administrative process, which centers its actions around the planning, organization, direction and control.

Walking along the path marked by UNESCO implies conceiving strategic planning as part of the management philosophy of universities. This is important because it allows managers to design a vision of an ideal educational system, where they implement aspects such as: self-maintenance, discipline, innovation, rationalism, productivity and competitiveness to form appropriate teaching and learning objectives and promote proactivity [14]. Also, [15] indicates that educational organizations are driven by a dynamic process, where the management actions of the teaching and learning processes play a fundamental role to achieve effective changes for the benefit of educational actors. Therefore, an effective management action allows the classroom teacher to know their work through the integral development of the students.

\section{B. Variable: Technologic Memory - Dimension: Social Promotion Projects}

Table 2 and Figure 2 show the results obtained for the dimension: Social Promotion Projects, through the indicators: prevention, participation, innovation, dynamization and methodology.

TABLE II. Dimension: Social Promotion Projects

\begin{tabular}{|c|c|c|c|c|c|c|c|c|c|c|c|c|}
\hline $\begin{array}{c}\text { Answer } \\
\text { categories }\end{array}$ & \multicolumn{2}{|c|}{ Always 5} & \multicolumn{2}{|c|}{ Almost always 4} & \multicolumn{2}{|c|}{ Sometimes 3} & \multicolumn{2}{|c|}{ Almost never 2} & \multicolumn{2}{|c|}{ Never 1} & \multirow{2}{*}{$\begin{array}{c}\text { weighted } \\
\text { average }\end{array}$} & \multirow{2}{*}{ Category } \\
\hline Indicators & af & $\%$ & af & $\%$ & af & $\%$ & af & $\%$ & & & & \\
\hline $\begin{array}{l}\text { Prevention } \\
\text { Item } 9 \\
\end{array}$ & 3 & 4.84 & 4 & 6.45 & 41 & 66.13 & 14 & 22.58 & -- & -- & 2.94 & $\begin{array}{l}\text { Moderately } \\
\text { unfavorable }\end{array}$ \\
\hline $\begin{array}{l}\text { Participation } \\
\text { Item } 10\end{array}$ & 4 & 6.45 & 8 & 12.90 & 20 & 32.26 & 25 & 40.32 & 5 & 8.06 & 2.69 & $\begin{array}{c}\text { Moderately } \\
\text { Favorable }\end{array}$ \\
\hline $\begin{array}{l}\text { Innovation } \\
\text { Item } 11 \\
\end{array}$ & 7 & 11.29 & 15 & 24.19 & 28 & 45.16 & 12 & 19.35 & -- & -- & 3.27 & $\begin{array}{c}\text { Moderately } \\
\text { Favorable }\end{array}$ \\
\hline $\begin{array}{l}\text { Dynamization } \\
\text { Item } 12\end{array}$ & 20 & 32.26 & 10 & 16.13 & 20 & 32.26 & 12 & 19.35 & -- & -- & 3.61 & Favorable \\
\hline $\begin{array}{l}\text { Methodology } \\
\text { Item } 13 \\
\end{array}$ & 9 & 14.52 & 8 & 12.90 & 25 & 40.32 & 20 & 32.26 & -- & -- & 3.10 & $\begin{array}{c}\text { Moderately } \\
\text { Favorable }\end{array}$ \\
\hline Averages & 8 & 13.87 & 9 & 14.52 & 27 & 43.23 & 17 & 26.77 & 1 & 1.61 & 3.12 & $\begin{array}{c}\text { Moderately } \\
\text { Favorable }\end{array}$ \\
\hline $\begin{array}{l}\text { Average of the } \\
\text { Dimension }\end{array}$ & \multicolumn{12}{|c|}{3.12} \\
\hline Category & & & & & & Ioderat & ly Fav & le & & & & \\
\hline
\end{tabular}

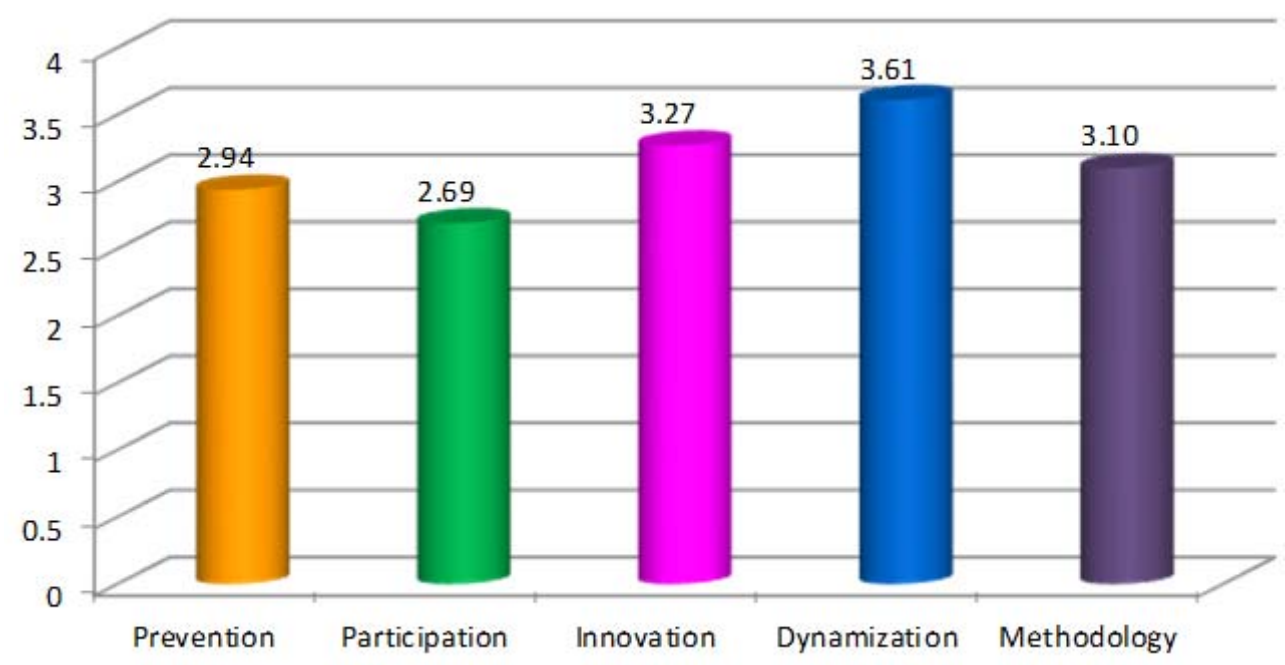

Fig. 2: Representation of the arithmetic means of the indicators of the dimension of Social Promotion Projects

The following was reported: the highest average of the responses was placed in the category at times, complemented by almost never, followed almost always, always and a low index in never. These results allow us to conclude that average teachers use the Technological Memory in activities inherent to their performance, 
when little encourage participation, prevention and innovation for the promotion of social behavior projects. It should be noted that the total arithmetic mean of the dimension obtained a value located in a moderately favorable category. These results are verified through each of the indicators that measure this dimension.

In the prevention indicator, it can be observed that most of the answers issued by teachers corresponded mostly to the option, sometimes complemented by almost never, which shows that very few teachers formulate public policies, create favorable environments and do not promote community participation and reorientation of community services. Similarly, the arithmetic average, positioned in the moderately favorable category, shows that a high efficiency and quality service is not promoted that allows improving and maintaining the quality of life of families.

The participation indicator shows a moderately favorable trend in the arithmetic mean. The same situation occurs in the arithmetic averages where the highest percentage was almost never, despite the position of the indicator sometimes indicates that teachers scarcely promote community participation and its importance for self-management, problem solving and satisfaction of needs, taking into account that participation in the management of teachers within universities is necessary for the promotion of social projects.

For its part, the innovation indicator presents a similar situation to obtain an arithmetic mean located in the moderately favorable category, and in addition to locating most of the answers in the option sometimes followed almost always. The results reflect that teachers mostly do not take advantage of the knowledge and skills of innovation, creativity and motivation of staff in Social Promotion projects.

In the dynamization indicator, the average was positioned in the favorable category, with averages per indicator located mostly in some times and always (equal value). These results are favorable in terms of the development of this indicator, considering that the teacher in their management for the promotion of social projects should be aware that learning does not require special conditions, is produced continuously and takes every opportunity, handling errors as opportunities.

In the methodology indicator, it is observed that the arithmetic average was placed in the moderately favorable category, which shows that teachers do not apply much knowledge, skills and techniques, for the execution of projects efficiently and effectively. This situation is also reflected in the arithmetic averages sometimes and almost never. According to the results obtained in the Social Promotion Projects dimension, a significant number of the teachers surveyed say that they do not apply prevention, participation, innovation, dynamization and methodology using technology memory as a teaching management tool in the university, considering that Information and communication technologies are having importance in educational centers.

In this regard, [16] states that projects are important because they are undertaken to meet individual and/or collective needs. Therefore, they are very important because they aim to take advantage of resources to improve the living conditions of a community. These ranges from the intention or thought to execute something, until the term or normal operation, that is, respond to decisions on the use of resources with the aim of increasing, maintaining or improving the production of goods or the provision of services. From this perspective, the technological memory as a teaching management tool in universities is of great help in Social Promotion projects, since it guides the search for an intelligent solution tending to solve human needs.

\section{Variable: Technologic Memory - Dimension: Use of the Technological Memory}

The general results for the Use of Technology Memory dimension through the Checklist, database and data Warehouse indicators are shown in Table 3 and Figure 3.

TABLE III. Dimension: Use of the Technological Memory

\begin{tabular}{|c|c|c|c|c|c|c|c|c|c|c|c|c|}
\hline $\begin{array}{l}\text { Answer } \\
\text { categories }\end{array}$ & \multicolumn{2}{|c|}{ Always 5} & \multicolumn{2}{|c|}{ Almost always 4} & \multicolumn{2}{|c|}{ Sometimes 3} & \multicolumn{2}{|c|}{ Almost never 2} & \multicolumn{2}{|c|}{ Never 1} & \multirow{2}{*}{$\begin{array}{c}\text { weighted } \\
\text { average }\end{array}$} & \multirow{2}{*}{ Category } \\
\hline Indicators & af & $\%$ & af & $\%$ & af & $\%$ & af & $\%$ & af & & & \\
\hline $\begin{array}{l}\text { Checklist } \\
\text { Ítem 14-15 }\end{array}$ & 6 & 9.68 & 22 & 35.48 & 24 & 38.71 & 10 & 16.13 & -- & -- & 3.39 & $\begin{array}{c}\text { Moderately } \\
\text { Favorable }\end{array}$ \\
\hline $\begin{array}{c}\text { Database } \\
\text { Ítem 16-17 }\end{array}$ & 12 & 19.35 & 15 & 24.19 & 20 & 32.26 & 15 & 24.19 & -- & -- & 3.39 & $\begin{array}{c}\text { Moderately } \\
\text { Favorable }\end{array}$ \\
\hline \begin{tabular}{|c} 
Data Warehouse \\
Ítem 18-19 \\
\end{tabular} & 10 & 16.13 & 20 & 32.26 & 25 & 40.32 & 7 & 11.29 & & -- & 3.53 & Favorable \\
\hline Averages & 9 & 15.05 & 19 & 30.64 & 23 & 37.10 & 11 & 17.20 & -- & -- & 3.44 & Favorable \\
\hline $\begin{array}{l}\text { Average of the } \\
\text { Dimension }\end{array}$ & \multicolumn{12}{|c|}{3.44} \\
\hline Category & \multicolumn{12}{|c|}{ Favorable } \\
\hline
\end{tabular}




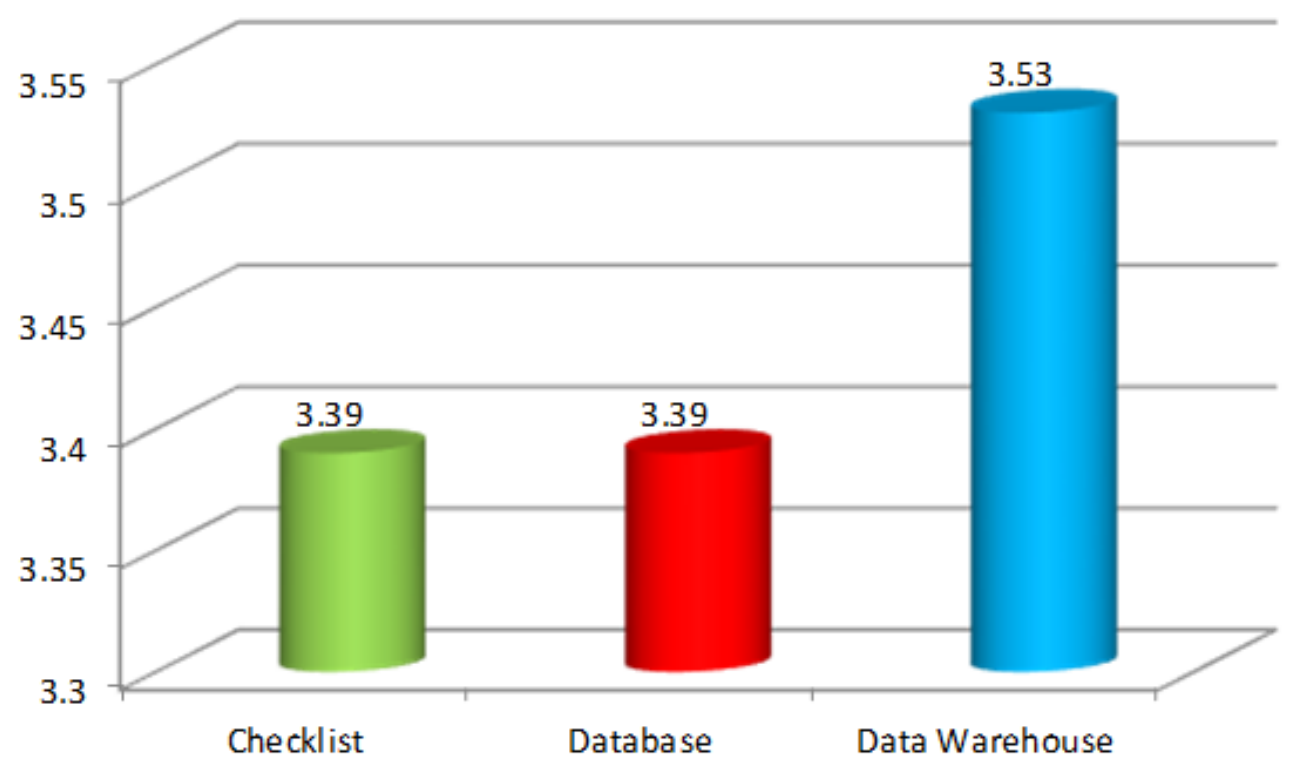

Fig. 3: Representation of the arithmetic means of the indicators of the dimension Use of the Technological Memory

In the previous results, the highest average was placed in the category sometimes, complemented in descending order by almost always, almost never and always; it was equivalent to a favorable and indicative trend that teachers consider that computer and electronic media significantly support classroom work, given that technological advances are the fundamental steps for the establishment of a university management process. In the same way, a general average arithmetic average of 3.44 corresponding to the favorable category is obtained, which corroborates the previous approach.

In the indicator Checklist, a moderately favorable trend is observed, in view of locating the highest percentages in some times and almost always, together with an arithmetic average positioned in a favorable category. The above allows us to infer that teachers use this checklist fairly to carry out the information in a correct manner, which serves as a basis for the preparation prior to the preparation of various projects.

Regarding the database indicator, the majority responses were located at some times and equally almost always and almost never. It should be noted that the arithmetic mean of this indicator was positioned in the moderately favorable category, indicating that teachers use little this technological memory, which allows them to store, organize, retrieve, communicate and manage in a way that would be impossible without a computer.

On the other hand, the Warehouse indicator shows that responses were distributed mostly in some cases and almost always, these values show a favorable trend as well as the arithmetic mean of this indicator. The results allow interpreting a high willingness on the part of teachers to use this data, as a solution to the global informational needs of the university to effectively developer the projects of the Social Promotion Program. It is evident, according to the results obtained in this dimension, that the teachers surveyed use the Technological Memory through the Checklist, the database and the Data Warehouse maintain the effectiveness as well as the competitiveness of the university. Therefore, in collaborative working environments it is very important to have a robust infrastructure of information technologies to develop social promotion projects.

In this order of ideas, [17] argues that the use of technology memory generates new opportunities for access to information, create capacities, improve productivity and promote development, in short, allow advance in the creation of equal options. Therefore, they become an increasingly powerful tool, as they participate in global markets, promote more transparent political management, improve the provision of basic services and increase opportunities.

TABLE IV. Dimension: Summary of the variable

\begin{tabular}{|c|c|c|}
\hline Dimensions & Average & Category \\
\hline Teaching Management & 2.86 & Moderately Favorable \\
\hline Social Promotion Projects & 3.12 & Moderately Favorable \\
\hline Use of the Technological Memory & 3.44 & Favorable \\
\hline Average of the Variable & 3.14 & Moderately Favorable \\
\hline
\end{tabular}


The results obtained show an average of 3.14, which is equivalent to a moderately favorable trend and indicates that the Technology Report is not being considered at the university under study, which shows that there are weaknesses in the management of information and communication technology, through the teaching management, projects of social promotion and use of the technological Memory for its development and projection. However, the foregoing differs with that indicated by [18], who defines technological memory as the systematic record of information itself, whether in people, teams, organizations or processes, whose objective is to promote technological learning within an organization.

\section{CONCLUSION}

In the diagnosis of the management carried out by the teacher for the development of projects of the Social Promotion Program in the University of La Guajira, Fonseca headquarters, a moderately favorable tendency was evidenced regarding the functions of planning, organization, direction and control, by how much do they reflect a median application on the part of the teachers, which indicates that the projects of Social Promotion little plan taking into account the technological Memory, as well as establishing actions with the members of the community for the elaboration of the Social Promotion projects. In terms of describing Social Promotion projects, it was shown that the moderately favorable trend prevails, because teachers have weaknesses in the use of checklists and manuals present in the Technology Report, likewise, little use of the base of data for the realization of said projects.

In general, the majority of teachers sparsely apply prevention, participation, innovation, dynamization and methodology taking into account the technological memory. In the same way, the majority opinion of the educated researchers is considered, to conclude that these moderately use the Technological Memory through the Checklist, the database and the Data Warehouse for the elaboration of the Social Promotion projects. They also guide their actions in the classroom aimed at preventing the incorporation of these projects, as well as allowing the participation of the community in the development of Social Promotion projects.

\section{REFERENCES}

[1] R. Hernández, "Impact of ICT on Education: Challenges and Perspectives,” Journal of Educational Psychology - Propósitos y Representaciones, vol. 5, issue 1, pp. 337-347, 2017.

[2] J. Martín-Gutiérrez, P. Fabiani, W. Benesova, M. D. Meneses and C. E. Mora, "Augmented reality to promote collaborative and autonomous learning in higher education,” Computers in Human Behavior, vol. 51, pp. 752-761, 2015.

[3] T. Dicke, J. Elling, A. Schmeck and D. Leutner, "Reducing reality shock: The effects of classroom management skills training on beginning teachers,” Teaching and Teacher Education, vol. 48, pp. 1-12, 2015.

[4] D. C. Hambrick and P. A. Mason, "Upper echelons: The organization as a reflection of its top managers," Academy of management review, vol. 9, issue 2, pp. 193-206, 1984.

[5] F. Wang, Z. Cheng, C. Keung and A. Reisner, "Impact of manager characteristics on corporate environmental behavior at heavypolluting firms in Shaanxi, China,” Journal of Cleaner Production, vol. 108, pp. 707-715, 2015.

[6] C. Henaku and M. Pobbi, "Measuring Teacher Classroom Management Skills: A Comparative Analysis of Distance Trained and Conventional Trained Teachers,” Journal of Education and Practice, vol. 8, issue 10, pp. 54-64, 2017.

[7] F. Sadik and T. Akbulut, "An Evaluation of Classroom Management Skills of Teachers at High Schools (Sample from the City of Adana),” Procedia-Social and Behavioral Sciences, vol. 191, pp. 208-213, 2015.

[8] S. F. Fong, P. E. Ch'ng and F. P. Por, "Development of ICT competency standard using the Delphi technique," Procedia-Social and Behavioral Sciences, vol. 103, pp. 299-314, 2013.

[9] E. J. Instefjord and E. Munthe, "Educating digitally competent teachers: A study of integration of professional digital competence in teacher education,” Teaching and Teacher Education, vol. 67, pp. 37-45, 2017.

[10] R. Kumar, Research methodology - a step-by-step guide for beginners. Londres, England: SAGE Publications Ltd., 2011.

[11] E. Babbie, The basics of social research, 5th ed. Belmont: Wadsworth Cengage Learning, 2011.

[12] B. Beins and M. McCarthy, Research Methods and Statistics. United States of America: Pearson education Inc., 2012.

[13] D. Sadeghi and S. Sadeghi, "A typology model for creativity managers based on reference points and their characteristics," ProcediaSocial and Behavioral Sciences, vol. 47, pp. 2219-2224, 2012.

[14] S. Javan and F. Aghashahi, "An Investigation on Strategic Management Success Factors in an Educational Complex," Procedia Social and Behavioral Sciences, vol. 230, pp. 447-454, 2016.

[15] E. Ruskovaara, M. Hämäläinen, and T. Pihkala, "HEAD teachers managing entrepreneurship education-Empirical evidence from general education,” Teaching and Teacher Education, vol. 55, pp. 155-164, 2016.

[16] D. C. Chou, "Applying design thinking method to social entrepreneurship project," Computer Standards \& Interfaces, vol. 55, pp. 7379, 2017.

[17] T. Dewett and G. R. Jones, “The role of information technology in the organization: a review, model, and assessment," Journal of management, vol. 27, issue 3, pp. 313-346, 2001.

[18] D. A. Hernández, J. G. Sanchez, and N. M. Caira, "Technological memory types in technology of information service in banking entities of the Zulia state,” Revecitec Urbe, vol. 4, issue 1, 2013. 


\section{AUTHOR PROFILE}

Esther S. Zárate works as part-time professor at the University of La Guajira (Colombia). Mrs. Zárate completed his magister from Rafael Belloso Chacín University (Colombia).

Raúl J. Martelo works as full-time professor at the University of Cartagena (Colombia). Mr. Martelo completed his magister from Industrial University of Santander (Colombia). Mr. Martelo completed his undergraduate in Systems Engineering at the Industrial University of Santander.

David Franco works as full-time professor at the University of Cartagena (Colombia). Mr. Franco completed his magister from Monterrey Institute of Technology and Higher Education (México). Mr. Franco completed his undergraduate in Systems Engineering at the Technological University Foundation Comfenalco. 